\title{
The Manuscript Context of the Middle Dutch Fabliaux
}

\section{Bart Besamusca}

$\mathrm{I}$

n the 1999 volume of essays in honor of Per Nykrog, Keith Busby discussed five anthology manuscripts containing more than ten Old French fabliaux, focusing on what he called "the local dynamics of the codex." By studying the manuscript context of these tales, Busby convincingly demonstrated the productivity of this new approach for the corpus of comic tales, which were highlighted by Nykrog in Les fabliaux (1957), an indisputable monument of fabliaux scholarship. ${ }^{2}$ Some years later, in what will most certainly prove a milestone in the field of medieval literary studies as well, Busby applied his point of view to Old French verse narratives. ${ }^{3}$ In this contribution I would like to pursue his line of reasoning by discussing the manuscript context of the Middle Dutch fabliaux. Regrettably, Netherlandists have studied the Dutch stories without paying much attention to their material transmission in codices, much like the great majority of Romanists analyzing French comic tales. ${ }^{4}$ Busby's conclusion with regard to Old French fabliaux might just as well apply to Middle Dutch tales: "Reading fabliaux in their manuscript context reveals an important

\footnotetext{
* I would like to thank Frank Brandsma, Hans van Dijk, and Jessica Quinlan for their comments on earlier drafts of this article.

${ }^{1}$ Keith Busby, "Fabliaux and the New Codicology," in The World and Its Rival: Essays on Literary Imagination in Honor of Per Nykrog, ed. Kathryn Karczewska and Tom Conley (Amsterdam: Rodopi, 1999) 137-60, here 160.

${ }^{2}$ See Per Nykrog, Les fabliaux, 2nd ed. (Geneva: Droz, 1973).

${ }^{3}$ Keith Busby, Codex and Context: Reading Old French Verse Narrative in Manuscript, 2 vols. (Amsterdam: Rodopi, 2002). The book includes an expanded version of Busby's 1999 essay (437-63).

${ }^{4}$ See, however, Richard Trachsler, "Uncourtly Texts in Courtly Books: Observations on MS Chantilly, Musée Condé 475," in Courtly Arts and the Art of Courtliness, ed. Keith Busby and Christopher Kleinhenz (Cambridge: Brewer, 2006) 67992.
} 
aspect of their significance for early readers or listeners which would otherwise remain concealed." 5

In the course of the fourteenth century, Middle Dutch authors started to compose short verse texts, possibly in reaction to the changing taste of their audiences, who seem to have grown tired of the long chivalric romances. ${ }^{6}$ The only catalogue of these so-called "sproken," which were supposedly written by itinerant professional storytellers (referred to as "sprekers," speakers), lists 358 extant texts. ${ }^{7}$ Although most of these poems are typical examples of moralizing literature, displaying an overtly didactical bias, the corpus also includes a small group of comical tales. ${ }^{8}$ Comparable to the problem of defining the corpus of Old French "contes à rire," the exact number of these Middle Dutch fabliaux, the so-called "boerden," is uncertain.

In 1957, Cornelis Kruyskamp published the first collective edition of the "boerden," consisting in all of nineteen texts. ${ }^{9}$ However, his selection proved to be disputable. In his 1996 thesis, Fred Lodder pleaded for the exclusion of five texts, arguing on formal grounds that they should not be characterized as narratives. ${ }^{10}$ To balance the loss of these texts, he also proposed to add a number of stories to the corpus of "boerden," analyzing eighteen tales in the extremely useful catalogue which completes his thesis (215-29). One of these texts was rejected for inclusion in his 2002 edition of the Middle Dutch fabliaux (accompanied by verse translations in modern Dutch). ${ }^{11}$ For practical reasons, I have adopted Lodder's selection of texts in his edition as my

\footnotetext{
5 "Fabliaux" 159; cf. also Codex 462.

${ }^{6}$ This explanation is put forward by Frits van Oostrom in 1984 in his Aanvaard dit werk: Over Middelnederlandse auteurs en hun publiek (Amsterdam: Prometheus, 1992) 99-116, 293-96 (reprint of the 1984 article).

${ }^{7}$ Dini Hogenelst, Sproken en sprekers: Inleiding op en repertorium van de Middelnederlandse sproke, 2 vols. (Amsterdam: Prometheus, 1997).

${ }^{8}$ For a survey in German of the corpus of "sproken" and the scholarship devoted to it, see my "In corten wort. Die mittelniederländische Kurzepik (sproken)," in Mittelalterliche Novellistik im europäischen Kontext. Kulturwissenschaftliche Perspektiven, ed. Mark Chinca, Timo Reuvekamp-Felber, and Christopher Young (Berlin: Erich Schmidt Verlag, 2006) 347-72.

9 De Middelnederlandse boerden, ed. Cornelis Kruyskamp ('s-Gravenhage: Martinus Nijhoff, 1957). For an earlier attempt to collect these texts, see Dit sijn X goede boerden, ed. Eelco Verwijs ('s-Gravenhage: Martinus Nijhoff, 1861).

${ }^{10}$ Fred J. Lodder, Lachen om list en lust. Studies over de Middelnederlandse komische versvertellingen (Ridderkerk: Boekhandel De Ridderhof, 1996) 15, 26-27.

${ }^{11}$ Van de man die graag dronk en andere Middelnederlandse komische verhalen, ed. Fred Lodder, trans. Karel Eykman (Amsterdam: Prometheus / Bert Bakker, 2002).
} 
point of departure for this essay. This implies that we are dealing with seventeen tales, which have come down to us in seven manuscripts. Perhaps one of the few advantages of these modest numbers is that they allow me to include all tales and codices in the discussion below. ${ }^{12}$ The manuscripts are presented in chronological order.

\section{Manuscript Brussels, Royal Library, II 1171}

The oldest codex containing Middle Dutch fabliaux is a composite volume, consisting of two originally distinct parchment manuscripts which were probably brought together around $1500 .{ }^{13}$ Both the first codex, a copy of parts of Jacob van Maerlant's Spiegel historiael and the verse narrative Van den VII vroeden van binnen Rome, and the one that interests us here date from the first half of the fourteenth century. ${ }^{14}$ The second manuscript consists of 94 folios (fols. 33-80, 285-332; the misplacement is due to an error which occurred during rebinding) and is written in two columns of 40 lines. The collection of texts includes three "boerden": Dits van den vesscher van Parijs (fols. 328va-330rb), Dits van Heilen van Beersele (fols. 330rb-331va) and Van der vrouwen die boven haren man minde (fols. 332ra-332vb).

In the Middle Dutch rendition of Le Pescheor de Pont seur Saine, Dits van den vesscher van Parijs (Of the fisherman of Paris; 290 vv.),

${ }^{12}$ Regrettably, very few critical studies concerning "boerden" are available in languages other than Dutch. One may consult the following publications: Willem Noomen, "Une réplique néerlandaise d'un fabliau français: Le Pescheor de Pont seur Saine et Dits van den vesscher van Parijs," in Et c'est la fin pour quoy sommes ensemble: Hommage à Jean Dufournet, 3 vols. (Paris: Champion, 1993), vol. 3, 102944; Bart Besamusca, "The First-Person Narrator in Middle Dutch Fabliaux," in The Court and Cultural Diversity, ed. Evelyn Mullally and John Thompson (Cambridge: Brewer, 1997) 405-13; Fred Lodder, "Of Wives and Men: Middle Dutch Fabliaux on a Hot Urban Issue," in Risus Mediaevalis: Laughter in Medieval Literature and Art, ed. Herman Braet, Guido Latré, Werner Verbeke (Leuven: Leuven UP, 2003), 181-94. In addition, six Middle Dutch tales are available in modern English, translated by David Johnson. See Medieval Comic Tales, ed. Derek Brewer, 2nd ed. (Cambridge: Brewer, 1996) 125-42. When discussing these stories below, I will refer to the translations in notes.

${ }^{13}$ See Jos A.A.M. Biemans, Onsen Speghele Ystoriale in Vlaemsche. Codicologisch onderzoek naar de overlevering van de Spiegel historiael van Jacob van Maerlant, Philip Utenbroeke en Lodewijk van Velthem, met een beschrijving van de handschriften en fragmenten, 2 vols. (Leuven: Peeters, 1997), vol. 2, 426-31.

${ }^{14}$ The date given in Biemans's catalogue applies to the first codex only. I would like to thank him for confirming the date of the second codex by e-mail (15-2-2008). 
the male character is married to a woman who claims to have an aversion to sex. ${ }^{15}$ Lacking any sensitivity, the fisherman uses the cut off penis of a dead monk, which he declares to be his own member, to prove that his wife is just pretending. The second story, Dits van Heilen van Beersele (Of Heile of Beersele; 190 vv.), has a well-known analogue in English literature: "The Miller's Tale" in Chaucer's Canterbury Tales. ${ }^{16}$ In the Dutch text, the Antwerp prostitute Heile is visited by a miller, a priest, and a smith at different hours of the same evening. As in Chaucer's tale, the outcome of their visit is disastrous: the smith kisses the priest's behind; the priest's posterior is branded with a hot iron and he falls into the privy; the miller breaks his arm and thighbone. The moral of the tale, according to the narrator: this is what happens to men who visit prostitutes. The subject of the third "boerde" is clearly indicated by its title, Van der vrouwen die boven haren man minde (Of the woman who committed adultery; $132 \mathrm{vv}$ ). ${ }^{17}$ The cunning married woman makes love to her lover in the conjugal bed without being caught in the act by her sleeping husband. When he wakes up, she deceives him, claiming that he has been alarmed by the presence of a calf (in stead of her lover) in their bed.

The most striking parallel between the three stories concerns the female characters. Each of the tales presents a woman in a strong, negatively oriented, connection with sexuality. While Heile has a remarkable flourishing business as a prostitute, the other two women are clearly obsessed by sex. We see a clustering of texts here, joined together by a common theme. Nor is this structuring "according to the principle of similitude" limited to the three "boerden." 18 For the other two short texts in the miscellany also fit into this context. Van den vesscher is preceded by the poem Van der wiue wonderlijcheit (Of the peculiarity of women), which criticizes a number of supposed female vices. Women are denounced for the way they dress, their eagerness to paint their faces, their recalcitrance, their quarrelsome nature, and their

\footnotetext{
${ }^{15}$ Van de man die graag dronk 32-47. For a study of the adaptation technique, see Noomen, "Une réplique néerlandaise."

${ }^{16}$ Van de man die graag dronk 48-57. English translation by Stith Thompson in Sources and analogues of Chaucer's Canterbury Tales, ed. W.F. Bryan and Germaine Dempster (London: Routledge, 1958) 112-18. (The accompanying Dutch text edition is unreliable.) For a comparison of the Dutch and English tales, see Erik Hertog, Chaucer's Fabliaux as Analogues (Leuven: Leuven UP, 1991) 106-18.

${ }^{17}$ Van de man die graag dronk 58-65.

${ }^{18}$ With a minor change, I quote Busby "Fabliaux" 159; cf. also Codex 463.
} 
ability to deceive men. ${ }^{19}$ The second short poem, entitled Van dinghen die selden ghescien (Of things which seldom occur) is placed between Van Heilen van Beersele and Van der vrouwen. This text consists of an enumeration of unique things, like generous priests, worried rich people, and sensible barbers. Women are not excluded from the list, as the narrator seldom hears of beautiful women without a lover and vicious women who do not scold. ${ }^{20}$ These two "sproken" share with the three fabliaux a negative opinion on women.

Interestingly, the misogynistic bias of the five tales contributes to the meaning of the long text which precedes them. It is Heinric's Die Rose, one of the two Middle Dutch verse translations of Guillaume de Lorris' and Jean de Meun's Roman de la Rose. ${ }^{21}$ As early as the period when Heinric was at work, around 1300-1325, the French text was interpreted in radically different ways. As Kevin Brownlee and Sylvia Huot have observed: "Some [poets] read it as a celebration of human love; others as an erudite philosophical work; still others as a satirical representation of social and sexual follies. It was praised as an edifying treatise and condemned as lascivious and misogynistic." 22 A certain amount of information concerning Heinric's view on the Roman de la Rose can be deduced from his translation method. While he made a fairly faithful rendition, he considerably shortened the text, mostly in Jean de Meun's part. One abridgement in particular is striking: Heinric omitted the episode of almost 5,000 lines featuring Nature and Genius, with the exception of Genius' diatribe against the lack of discretion of women. He places it, remarkably enough, in the mouth of the narrator of the Middle Dutch text, thereby highlighting the misogynistic overtones. ${ }^{23}$ Taking into account the five short texts, one may conclude that this negative opinion on women holds for the text

\footnotetext{
${ }^{19}$ See Hogenelst, Sproken en sprekers, vol. 2, 198-99 (no. 274).

${ }^{20}$ See Hogenelst, Sproken en sprekers, vol. 2, 34-35 (no. 29).

${ }^{21}$ See Dieuwke E. van der Poel, De Vlaamse Rose en Die Rose van Heinric. Onderzoekingen over twee Middelnederlandse bewerkingen van de Roman de la Rose (Hilversum: Verloren, 1989). See also her English essays on this subject: "The Romance of the Rose and I: Narrative Perspective in the Roman de la Rose and its Two Middle Dutch Adaptations," in Courtly Literature: Culture and Context, ed. Keith Busby and Erik Kooper (Amsterdam: Benjamins, 1990) 573-83; "A Romance of a Rose and Florentine: The Flemish Adaptation of the Romance of the Rose," in Rethinking the Romance of the Rose: Text, Image, Reception, ed. Kevin Brownlee and Sylvia Huot (Philadelphia: Univ. of Pennsylvania Press, 1992) 304-15.

${ }_{22}$ Brownlee and Huot, Rethinking the Romance of the Rose 1.

${ }^{23}$ See Van der Poel, De Vlaamse Rose en Die Rose van Heinric 50-51.
} 
collection as a whole. The "dynamics of the codex," to which Busby refers, are clearly at work here.

The Brussels codex II 1171 and the other manuscripts which will be discussed in this essay are by no means luxury books. Their décoration, for instance, is modest, mostly limited to small colored initials, usually red, and rubricated capitals. Furthermore, none of the seven manuscripts is illustrated. Nevertheless, I should mention here that in MS II, 1171 the first capitals of the columns are somewhat enlarged and irregularly provided with grotesque human heads. The first capital of the first column on fol. 330r, for instance, is an enlarged "J," combined with the head of a man, whose main feature consists of a pronounced nose. ${ }^{24}$ As the text copied here is Dits van den vesscher van Parijs, one could obviously argue that the nose may be seen as a playful comment on the contents of the tale, which revolves around a penis. ${ }^{25}$ This interpretation must be rejected, however, as this manuscript features no shortage of heads with grotesque noses.

\section{The Van Hulthem manuscript}

The second codex containing Middle Dutch fabliaux is of prime importance for the study of Middle Dutch literature. No less than 214 texts are copied in this voluminous manuscript, now in the Royal Library of Brussels, shelf mark 15.589-623. Named after its last private owner, Charles van Hulthem, the book is known as the Van Hulthem manuscript. While the text collection probably came into being around 1400 in a cultural milieu associated with the church of Saint John the Baptist at Molenbeek, a village in the vicinity of Brussels, and with the aristocrat Willem van den Heetvelde, Lord of Koekelberg, the manuscript in which the collection has come down to us dates from the period $1405-1408 .{ }^{26}$ It is a paper codex, consisting of 241 folios (originally at least 278), written by one scribe in two columns of 45 or 46 lines. The miscellany, now opening with the well-

\footnotetext{
${ }^{24} \mathrm{Cf}$. the illustration opposite the title page of Kruyskamp, De Middelnederlandse boerden.

${ }^{25}$ On the connection between these two body parts, see Jan Goossens, De gecastreerde neus. Taboes en hun verwerking in de geschiedenis van de Reinaert (Leuven and Amersfoort: Acco, 1988).

${ }^{26}$ See Herman Brinkman, "Het wonder van Molenbeek. De herkomst van de tekstverzameling in het handschrift-Van Hulthem," Nederlandse Letterkunde 5 (2000): 21-46.
} 
known Reis van Sint Brandaan (Voyage of St. Brendan) due to the loss of the first text, contains an enormous variety of prose and verse texts, some famous, some virtually unknown, including songs, prayers, plays, maxims, tales and excerpts. ${ }^{27}$ There are eight Middle Dutch fabliaux, i.e. nearly half of Lodder's selection.

The tale Dits vanden man die gherne dranc (Of the man who loved to drink; $202 \mathrm{vv}$.), copied on fols. 31ra-32rb, presents a man who can be found in the pub day and night. Returning home, he manages to temper his wife's fury by promising her to mend his ways and by pleasing her in bed. ${ }^{28}$ On fols. $38 \mathrm{rb}-38 \mathrm{vb}$ begins Tgoede wijf maect den goeden man ende de goeden man maect tgoede wijf (A good wife makes a good man, a good man a good wife; $88 \mathrm{vv}$.). In this tale a clever merchant outwits his wife, who intends to commit adultery with his rich colleague. Disguised as her supposed lover, he succeeds in humiliating her. ${ }^{29}$ The third "boerde," entitled Wisen raet van vrouwen (The cleverness of women; $220 \mathrm{vv}$.) and copied on fols. 39va-40va, is the delightful story of a clever young girl, who is locked up by her father in order to protect her honor. The events pass off as in Boccaccio's Decameron (the third story of the third day): with the unintentional aid of a foolish friar who does not understand the double entendre of her messages, she manages to inform a young man of her love and guide him to her room. ${ }^{30}$

Further on in the manuscript, on fols. 112va-113ra, the scribe wrote the tale Van enen man die lach gheborgen in ene scrine (Of a man who lay hidden in a chest; $72 \mathrm{vv}$.), which also resembles a story in Boccaccio, the eighth story of the eighth day. A man humiliates his unfaithful wife by raping her lover's wife on a chest in which her husband is hiding. ${ }^{31}$ The fifth "boerde," copied on fols. 113va-114vb, is an adaptation of Jean Bodel's Gombers et les deus Clers. The bispel van II clerken (An example of two clerks; $234 \mathrm{vv}$.) tells the tale of two

\footnotetext{
${ }^{27}$ For an edition of the whole text collection, see Het handschrift-Van Hulthem. Hs. Brussel, Koninklijke Bibliotheek van België, 15.589-623, ed. Herman Brinkman and Janny Schenkel, 2 vols. (Hilversum: Verloren, 1999).

${ }^{28}$ Van de man die graag dronk $70-81$.

${ }^{29}$ Van de man die graag dronk 82-87.

${ }^{30}$ Van de man die graag dronk 88-99; translation: Medieval Comic Tales 127-29. Frank Brandsma and Orlanda Lie have provided an excellent analysis of the tale in Klein kapitaal uit het handschrift-Van Hulthem, ed. H. Hans van Dijk et al. (Hilversum: Verloren, 1992) 32-41.

${ }^{31}$ Van de man die graag dronk 100-05.
} 
clerks who manage to fulfill their desires with the aid of cunning. One of them seduces their host's daughter by offering her a (fake) ring, while the second one manages to make love to the lady of the house after rearranging the furniture so that her husband goes to sleep in the wrong bed. ${ }^{32}$

The next fabliau occurs more than forty folios further on. Vanden cnape van Dordrecht (Of the lad from Dordrecht; 166 vv.), copied on fols. 148ra-149ra, is a variant of the Old French tale Le foteor. It is the story of a gigolo who is invited by the wife of a bailiff and subsequently forces that same officer to pay for the services rendered. ${ }^{33}$ Immediately following, on fols. 149ra-150rb, the scribe wrote Van III gesellen die den bake stalen (Of three companions who stole a side of bacon; $224 \mathrm{vv}$ ). This tale relates of a farmer, who has renounced his life as a thief, and two visitors, who are his former partners in crime. The three men play a series of tricks on each other in order to get hold of the farmer's side of bacon. The trickery ends to the advantage of the farmer. ${ }^{34}$ The eighth and final "boerde" in the collection, copied on fols. 164ra-164vb, is entitled Van Lacarise den katijf die een pape sach bruden sijn wijf (Of the foolish Lacarijs who saw a priest screwing his wife; $104 \mathrm{vv}) .^{35}$ The male character of this tale is fooled by his lustful wife. In Lacarijs' presence she makes love to a priest, having convinced her husband that he cannot protest against her behavior because he is dead. ${ }^{36}$

The original function of the Van Hulthem manuscript is a disputed issue in Dutch scholarship. Some critics argue that the codex served as an exemplar in a scriptorium. This point of view is based on the fact that at the end of most texts, which are all numbered, the scribe has added a specification of the number of lines he wrote. This would, so the reasoning goes, help to calculate quickly the costs of a copy. However, this hypothesis is rejected by other critics, who assume that

\footnotetext{
${ }^{32}$ Van de man die graag dronk 106-19; translation: Peter G. Beidler, "The "Reeve's Tale" and its Flemish Analogue," Chaucer Review 26 (1992): 283-92, here 284-87. For a comparison of the different versions of the story, see Hertog, Chaucer's Fabliaux 61-84.

${ }^{33}$ Van de man die graag dronk 120-29; translation: Medieval Comic Tales 130-31.

${ }^{34}$ Van de man die graag dronk 130-41; translation: Medieval Comic Tales 139-42.

35 A later hand has censured the tale's title, by changing "een pape" into "een ander" (another man).

${ }^{36}$ Van de man die graag dronk 142-47; translation: Medieval Comic Tales 132-33.
} 
the manuscript contains a privately owned text collection. ${ }^{37}$ One point in which there is no disagreement, however, concerns the clustering of texts clearly visible in the manuscript. ${ }^{38}$ A convincing example concerns the drama texts, numbered 169-70, 205-07, and 209-11, which usually involve a pair of plays: a secular drama ("abel spel") is followed by a farce ("sotternie"). ${ }^{39}$ Whether this clustering of texts throughout the manuscript is a result of the availability of exemplars at the time of copying or indicates a deliberate juxtaposition of related texts, remains unclear. Sarah Westphal has strongly argued in favor of the latter, referring to comparable "elements of the shared poetics of compilation" in German manuscripts. ${ }^{40}$

I would like to suggest that reading the eight fabliaux in the context of the Hulthem manuscript allows us to distinguish five clusters. First, the tale Dits vanden man die gherne dranc (no. 20) is preceded by a number of prayers (nos. 15-19) and immediately followed by Dmeisken metten sconen vlechten (The girl with the beautiful tresses), a lyrical text describing a girl's charms in unveiled language (no. 21), which is followed in turn by a number of serious secular and religious texts (nos. 22-27). The two frivolous texts are, therefore, surrounded and outnumbered by the other texts. In their depiction of female characters, they contrast in particular with two of the prayers, which are concerned with Mary (no. 18) and a number of women saints (no. 19). The second cluster I would like to point out is made up of, among others, Tgoede wijf maect den goeden man ende de goeden man maect tgoede wijf (no. 28) and Wisen raet van vrouwen (no. 30), which evidently share the theme of cunning. However, the texts which come before and after consist of devotions to Mary (nos. 26, 27), a serious love letter addressing a woman (no. 29) and a great number of religious texts, in particular prayers (from no. 31 onwards). This context

\footnotetext{
${ }^{37}$ See Het handschrift-Van Hulthem, vol. 1, 26-28.

${ }^{38}$ See Het handschrift-Van Hulthem, vol. 1, 29-30.

39 See Hans van Dijk, "The Drama Texts in the Van Hulthem Manuscript," in Medieval Dutch Literature in its European Context, ed. Erik Kooper (Cambridge: Cambridge UP, 1994) 283-96.

${ }^{40}$ Sarah Westphal, "The Van Hulthem MS and the Compilation of Medieval German Books," in Codices Miscellanearum: Brussels Van Hulthem Colloquium 1999, ed. Ria Jansen-Sieben and Hans van Dijk (Brussels: Archives et Bibliothèques de Belgique, 1999) 71-89, here 78. See also her Textual Poetics of German Manuscripts 1300-1500 (Columbia: Camden House, 1993).
} 
suggests that the clustering as a whole is concerned with the portrayal, both positive and negative, of women.

The third cluster involves Van enen man die lach gheborgen in ene scrine (no. 131) and Een bispel van II clerken (no. 133). The text in between is a song about a beguine making love, Van eenre baghinne (no. 132). The common theme is sex. These texts are preceded and followed by didactic texts (nos. 127-30, 134-138), for which it seems hardly possible to point out convincing thematic parallels. In the fourth cluster, two fabliaux are present: Vanden cnape van Dordrecht (no. 151) and Van III gesellen die den bake stalen (no. 152). Westphal would probably term these two successive tales dealing with cunning a "dyad," which she defines as "the pointed juxtaposition of two couplet texts in what appears to be the textual equivalent of the couplet rhyme." ${ }^{41}$ Including parts of Maerlant's Historie van Troyen and a warning against frequenting the tavern, the texts which come immediately before and after are didactical (nos. 143-50, 153-58) and would seem to share no common focus.

The fifth cluster is concerned with secular love. It opens with the tragic story of Pyramus and Tisbe (no. 159), two love songs (nos. 16061 ) and the Borchgravinne van Vergi (no. 162), the sad story of the Chatelaine of Vergi. Then it is time for something completely different, i.e. unrestrained lust, as demonstrated by Van Lacarise den katijf (no. 163) and an erotic song, Dits vanden tanden (Of the tooth), each stanza of which ends with the refrain "Ic trecke haer vte maer enen tant" (I am only extracting a tooth from her). This line is the casual reply the "I"-witness receives from a lollard whom he catches in the act with a beguine (no. 164). After a short diatribe against bad women (no. 165) and a prayer to Mary (no. 166), two more texts on ideal love follow (nos. 167-68), including Van der feesten een proper dinc (no. 167). This cluster seems to be based on the contrast between two forms of love. ${ }^{42}$

\footnotetext{
${ }^{41}$ Westphal, "The Van Hulthem MS" 79.

${ }^{42}$ Wim P. Gerritsen has suggested that the Borchgravinne van Vergi and Van Lacarise den katijf form a dyad. See his "Het verzamelhandschrift in de litteratuurgeschiedenis," Queeste 5 (1998): 182-88, here 187, n. 14.
} 


\section{The Comburg manuscript}

Like the Van Hulthem manuscript, the Comburg manuscript is of utmost importance for the study of Middle Dutch literature. Named after its place of discovery, the codex, now in the Württembergische Landesbibliothek of Stuttgart (shelf mark: Cod. poet. et phil. $2^{\circ} 22$ ), is a voluminous composite tome (346 folios), consisting of six parchment codices, which were mostly produced in the period $1400-1415 .^{43}$ Some of the six or seven scribes copied parts of several manuscripts, which strongly suggests that some kind of collaboration took place. In recent research, it has been convincingly argued that they were professional scribes, working in Ghent. ${ }^{44}$ The focus of the contents is on didactic and moralistic literature.

In manuscript IV (fols. 179-234) we find the only fabliau in the whole collection. The codex, written in two columns of 42 lines, opens with the Reis van Sint Brandaan, followed by the undisputed masterpiece of Middle Dutch literature, Van den vos Reynaerde, a number of religious prose texts, didactical verse narratives and, in conclusion, four short tales. ${ }^{45}$ The second to last text, copied on fols. 233vb-234rb, is the "boerde" Van der weldaet die de duuele dede (Of the kindness done by the devil; $72 \mathrm{vv}$.). In order to punish a nun who detests him, the devil makes her fall in love with a monk. Just as they are making love, he removes their bed to the choir, claiming that he wanted to prevent their absence from matins. ${ }^{46}$

Whereas Van der weldaet die de duuele dede can be related to the Reis van Sint Brandaan and Van den vos Reynaerde on the grounds of its humor, it is hard to imagine a connection with the three short tales which come immediately before and after and provide a description of bad servants (no. IV.9), relate a miracle carried out by Mary (no.

\footnotetext{
${ }^{43}$ For an edition of the whole text collection, see Het Comburgse handschrift. Hs. Stuttgart, Württembergische Landesbibliothek, Cod. poet. et phil. $2^{\circ} 22$, ed. Herman Brinkman and Janny Schenkel, 2 vols. (Hilversum: Verloren, 1997).

${ }^{44}$ Herman Brinkman and Herman Mulder, "Recht, historie en schone letteren: het arbeidsterrein van een Gents kopiistencollectief. Hs. Brussel KB 16.762-75 en het Comburgse handschrift," Queeste 10 (2003): 27-78.

45 Recently, Van den vos Reynaerde has become available in an edition accompanied by an English translation. See Of Reynaert the Fox: Text and Facing Translation of the Middle Dutch Beast Epic Van den vos Reynaerde, ed. André Bouwman and Bart Besamusca, trans. Thea Summerfield (Amsterdam: Amsterdam UP, 2009); includes a chapter on Middle Dutch by Matthias Hüning and Ulrike Vogl.

${ }^{46}$ Van de man die graag dronk 66-69.
} 
IV.10) and give all kinds of people advice on how to behave blamelessly (no. IV.12). It should be wise, I think, to accept the possibility that the scribe simply used the four tales to complete the last folios (fols. 231-34) of the manuscript's final quire. This interpretation is strengthened by the fact that the quire structure of the codex, consisting of seven undisturbed quaternions following Gregory's rule with regard to hair and flesh sides, does not show any irregularities. ${ }^{47}$ The scribe, it would seem, chose to add texts here rather than produce an irregular quire.

\section{Manuscript The Hague, Royal Library, 75 H 57}

The next codex containing Middle Dutch fabliaux to be discussed here was supposedly made around 1430-1450. The small book counts 67 paper folios, while a number of the original leaves are missing, and the scribe copied one column of 19 lines per page. ${ }^{48}$ It contains a wide variety of texts, including Van der feesten een proper dinc, which is also copied in the Van Hulthem manuscript (see above), De blauwe schuit (presenting the mock statutes of a group of people in charge of Shrovetide festivities), and a number of short tales, maxims and riddles. ${ }^{49}$ The function of this codex is disputed. In earlier research it was assumed that the book contained the repertoire of a "spreker" (speaker). However, as many texts are abridgements and deliberately left incomplete (i.e. not due to the loss of leaves), it is doubtful whether a professional storyteller could have used the book. Recent scholarship finds it more likely that the text collection was intended for private use. $^{50}$

Two Middle Dutch fabliaux have survived in this codex. The tale $I c$ prijs een wijf (I praise a woman; $80 \mathrm{vv}$.), the story of an innkeeper who is fooled by his wife and her lover, appears on fols. 19r-20v. The wife advises her husband to go to the garden, dressed up as herself. There

\footnotetext{
${ }^{47}$ See Het Comburgse handschrift, vol. 1, 53-57.

${ }^{48}$ See Herman Pleij, "Materiaal voor een interpretatie van het gedicht over de Blauwe Schuit (1413?). I," Spektator 1 (1971-72): 311-25, here 319-22.

${ }^{49}$ For an edition of almost the entire text collection, see Van vrouwen ende van minne, Middelnederlandsche gedichten uit de XIVde en XVde eeuw, ed. Eelco Verwijs (Leyden: Sijthoff, 1871)

${ }^{50}$ See Paul Wackers, "Het belang van de studie van verzamelhandschriften," in Middeleeuwse Verzamelhandschriften uit de Nederlanden, ed. Gerard Sonnemans (Hilversum: Verloren, 1996) 23-37, here 35-36.
} 
he is supposed to confront her lover, who beats "her," however, for cheating on "her" husband. Thus the wife and her lover overcome the innkeeper's distrust. ${ }^{51}$ The second fabliau, entitled Sint dat wi vrouwen garen (As long as we desire women; $358 \mathrm{vv}$.), copied on fols. $46 \mathrm{r}-54 \mathrm{v}$, features a poor knight who loves a beautiful widow, whereas she prefers for her part another knight, who is rich. With the aid of a series of tricks, the poor knight humiliates his rival and convinces the widow of his love. ${ }^{52}$

Reading these two "boerden" in their manuscript context is rewarding. Ic prijs een wijf (no. II) is preceded by a text on the nature of (ideal) love, Van der feesten (no. I), and followed by a collection of maxims and riddles, the majority concerned with love (no. III). In clear contrast to Van der feesten, the first fabliau presents the vulgar side of love. The second "boerde" (no. VIII), on the other hand, shows points of similarity with the texts which come before and after. The tale is preceded by a satirical poem on the rough manners of villains (no. VIIa) and the beginning (36 vv.) of Willem van Hildegaersberch's short text Vanden goeden vrouwen, which shows that a woman may fall in love with the wrong person (no. VIIb). ${ }^{53}$ These elements reoccur in the "boerde": the widow rejects the poor knight who is devoted to her, and she treats him badly, forcing him to sleep with the dogs. In addition, she acknowledges at the end of the tale that she had desired the rich knight for the wrong reasons. This idea is reiterated in the poem praising love (no. IX) which follows the "boerde."

\section{Two Hildegaersberch manuscripts}

Almost all of the Middle Dutch fabliaux, including the tales I have discussed so far, have come down to us in a unique copy. Two "boerden," both written by Willem van Hildegaersberch, form the exception to this rule. Both are preserved in two manuscripts. ${ }^{54}$ A paper codex completed in 1469, now in the Royal Library of Brussels (shelf mark: 15.659-61), contains 119 of Willem's "sproken" copied by the same

\footnotetext{
${ }^{51}$ Van de man die graag dronk 148-53.

${ }^{52}$ Van de man die graag dronk 154-73.

${ }^{53}$ See Van vrouwen ende van minne XXII-XXIII. See also Gedichten van Willem van Hildegaersberch, ed. Willem Bisschop and Eelco Verwijs (Utrecht: HES Publishers, 1981; reprint of `s-Gravenhage 1870) 73-74 (no. 34).

${ }^{54}$ See Theo Meder, Sprookspreker in Holland. Leven en werk van Willem van Hildegaersberch (circa 1400) (Amsterdam: Prometheus, 1991) 15-16, 23-24.
} 
scribe in two columns of around 40 lines (fols. 1-134), followed by a number of other verse and prose texts (fols. 135-89), written in part by another scribe. The second paper codex is a composite volume, dating from around 1480 and now located in the Royal Library of The Hague (shelf mark: $128 \mathrm{E} \mathrm{6).} \mathrm{Written} \mathrm{in} \mathrm{two} \mathrm{columns} \mathrm{of} 41$ lines, the first part (fols. 1-130) contains 117 "sproken" (due to the loss of folios; originally there were 120 texts), copied independently of the Hague manuscript, followed by a collection of maxims (fols. 128-30). The second part (fols. 131-92) is a copy of Dirc Potter's treatise Der minnen loep (The Course of Love).

On fols. 32vb-34rb of the Hague manuscript (Brussels: fols. 59ra60va) the scribe copied Vanden paep die sijn baeck ghestolen wert (Of the priest whose bacon was stolen; $232 \mathrm{vv}$.), the story of a greedy priest who is fooled by a young man. The priest is to absolve the boy of all his sins in exchange for half of a side of bacon which the lad is planning to steal. The priest is unpleasantly surprised when it turns out that the bacon he receives in exchange for his services was stolen from his own house. ${ }^{55}$ The second fabliau, copied on fols. 95ra-96va of the Hague manuscript (Brussels: fols. 88vb-90rb) also features a clergyman. In this tale, Vanden monick (Of the monk; $234 \mathrm{vv}$.), a lecherous friar has made a young girl pregnant. Having removed the friar's member, the devil advises him to prove his innocence by showing his congregation that he is handicapped. However, as soon as the friar, preaching from the pulpit, lifts his habit in order to rebut the accusations, the devil restores his erect penis. ${ }^{56}$

Willem van Hildegaersberch was an itinerant professional storyteller who regularly performed at the Dutch court in The Hague in the period $1383-1408 .^{57}$ The large number of texts attributed to him make abundantly clear that he was a very serious speaker, who was nearly always trying to improve the behavior of his audience by reciting pessimistic, overtly didactical and moralizing poems. ${ }^{58}$ On the grounds of their humor, the two fabliaux he composed seem out of place in the context of the Hague and Brussels manuscripts. However, this interpretation is

\footnotetext{
${ }^{55}$ Van de man die graag dronk 174-85; translation: Medieval Comic Tales 133-36.

${ }^{56}$ Van de man die graag dronk 186-99; translation: Medieval Comic Tales 136-39.

${ }^{57}$ See Meder, Sprookspreker 541-62.

${ }^{58}$ For an edition of his poems, see Gedichten van Willem van Hildegaersberch. For an analysis in English, see Frits Pieter van Oostrom, Court and Culture. Dutch Literature, 1350-1450, trans. Arnold J. Pomerans, foreword by James H. Marrow (Berkeley: Univ. of California Press, 1992) 37-76.
} 
based on the assumption that fabliaux were composed solely for the amusement of the listeners. The collections of "sproken" appear less heterogeneous if we accept a more nuanced point of view on the "boerden." Like one of the manuscripts discussed by Busby, Paris, BnF, fr. 19152, the Hague and Brussels codices show that these French and Middle Dutch fabliaux are not "merely outrageous comic tales," but "should be regarded as essentially moralizing." 59 They functioned as exempla, moral anecdotes warning against greed and lechery.

\section{Manuscript Brussels, Royal Library, II 144}

The youngest manuscript containing a Middle Dutch fabliau dates from the first decade of the sixteenth century. It is the first volume of a small composite codex (169 folios), consisting of four paper parts. Whereas the first part (fols. 1-113) is written by the same hand, the other parts are copied by later, seventeenth-century scribes. The contents of the first part include religious and secular songs, parodies, maxims, riddles, short tales and receipts, written in one column of 25 lines. ${ }^{60}$ Herman Pleij has argued convincingly that the codex should be regarded as a book for private use. Its owner was in all probability a (former) student, who compiled a modest Carmina Burana in the vernacular which he could use for recitation. ${ }^{61}$

On fols. $86 \mathrm{v}-88 \mathrm{r}$, the scribe wrote a comic tale, to which he gave a Latin title, as he did many of the other stories also. De eo qui duas volebat uxores (Of the man who wanted two wives; $80 \mathrm{vv}$.) features a young man who is convinced that he has to marry two women in order to fully satisfy his needs. Pressed by his father, he limits himself to one wife, who manages to exhaust him sexually within eight days. ${ }^{62}$ This tale is accompanied by a number of other texts concerning women, such as a dialogue between a father and son, who debate as to whether one should prefer wine to women (fols. $85 \mathrm{r}-85 \mathrm{v}$ ), and a song on the same theme (fols. $85 \mathrm{v}-86 \mathrm{v}$ ).

\footnotetext{
59 "Fabliaux" 152; cf. also Codex 451-52.

${ }^{60}$ See Robert Priebsch, "Aus deutschen Handschriften der Königlichen Bibliothek zu Brüssel," Zeitschrift für deutsche Philologie 38 (1906): 301-33, 436-67; 39 (1907): 156-79.

61 Herman Pleij, Dromen van Cocagne. Middeleeuwse fantasieën over het volmaakte leven (Amsterdam: Prometheus, 1997) 69-73.

${ }^{62}$ Van de man die graag dronk 200-05.
} 
The text which immediately catches the eye regarding the theme it shares with the comic tale, however, is a song beginning on fol. $82 \mathrm{r}$. The text, opening with the line "Te Venloe all in dye goyde statt" (In the good city of Venlo), cloaks its erotic contents in ambiguous terminology. ${ }^{63}$ The first-person narrator tells us that a young lady asked him if he could play on her fine instrument. When he states that he can play the lute, she assures him that she has the best lute a woman ever possessed. When they begin to play, it turns out that she wants to hear more and more music. This theme of the insatiable woman provides, of course, a striking parallel with the "boerde."

\section{Conclusion}

The codices discussed here show that there is much to be gained when we focus on reading "boerden" in their manuscript context. This point of view has enabled us to note the misogynistic emphasis of a text collection (Brussels, RL, II 1171), to discern a number of clusters, concerned with the portrayal of women, sex, cunning and the different sides of love in another collection (the Van Hulthem manuscript), and to discover thematic parallels and contrasts between texts which were copied in each other's vicinity (The Hague, RL, 75 H 57, and Brussels, RL, II 144). In addition, the approach has provided us with an argument confirming the opinion that fabliaux are not solely "contes à rire" (The Hildegaersberch manuscripts). The Comburg manuscript, finally, warns us not to look for parallels and contrasts at all costs. In some cases, texts may have been copied simply for reasons which have nothing to do with their contents.

At the end of this essay, I would like to change the perspective from the dynamics of the codex to the dynamics of an Utrecht establishment. It concerns Jan Primus, a public house located in the eastern part of town, famous for its astonishing variety of beers, both bottled and on draught. It is frequented by locals, students, university teachers, and tourists. When he held a position at Utrecht University, Keith always found time to visit Jan Primus for a drink with his friends. Legend has it that Keith, himself a passionate amateur brewer, always lures international colleagues on their first visit to Utrecht to this watering hole. I expect that he will spend more time in Utrecht after his retirement, and I suppose that, being one of the locals, I will meet

${ }^{63}$ Priebsch, “Aus deutschen Handschriften” 38 (1906): 464-65. 
him in Jan Primus when he regains his old position at the bar. For my part, I look forward to that occasion. 